\title{
AKTIVITAS PRIMER DAN PENDUKUNG RANTAI NILAI PRODUK PARE KRISPI UMKM D5 KARANGPLOSO MALANG
}

\author{
EFFY YUSWITA \\ Jurusan Sosial Ekonomi Pertanian, Fakultas Pertanian, Universitas Brawijaya \\ E-mail : e.yuswita@ub.ac.id
}

\begin{abstract}
ABSTRAK
Tujuan penelitian ini adalah 1) menganalisis aktivitas primer pada rantai nilai produk 2) menganalisis aktivitas pendukung pada rantai nilai produk di UMKM D5 Chrispy Karang Ploso Malang. Penelitian dilaksanakan selama 5 bulan yaitu pada bulan Juni 2020 hingga Oktober 2020. Responden yang dilibatkan dalam penelitian ini adalah pemilik UMKM D5 Chrispy Karangploso Malang. Analisis yang digunakan dalam penelitian ini adalah VCA (Value Chain Analysis) dengan melakukan pembobotan dan penilaian pada setiap aktivitas primer dan aktivitas pendukungnya. Hasil penelitian menunjukkan bahwa, aktivitas primer pada rantai nilai yang memiliki skor tertinggi yang sama besarnya adalah aktivitas logistik ke dalam dan aktivitas operasi, dengan kinerja yang excellent. Aktivitas primer yang memiliki skor terendah adalah aktivitas pemasaran dan penjualan dengan kinerja yang average. Pada aktivitas pendukung yang memiliki skor tertinggi adalah pada aktivitas pengembangan teknologi dengan kinerja yang average. Aktivitas pendukung yang memiliki skor terendah adalah aktivitas manajemen sumber daya manusia dengan kinerja yang poor. Untuk mencapai kinerja yang excellent perlu ada perubahan kinerjanya. Untuk aktivitas yang sudah excellent kinerjanya perlu dipertahankan. Ini merupakan potensi keungggulan bersaing.
\end{abstract}

Kata kunci : Aktivitas primer, aktivitas pendukung, keunggulan bersaing

\section{PENDAHULUAN}

Persaingan di era globalisasi menuntut perusahaan penyedia barang atau jasa untuk selalu tanggap dan jeli dalam apa yang terjadi saat ini. Terobosan baru dalam dunia usaha yaitu melalui strategi bersaing (Melissa C.E, 2018). Untuk menganalisis sumber keunggulan bersaing perusahaan, rantai nilai merupakan alat analisis yang tepat untuk digunakan.

Rantai nilai terdiri atas 2 aktivitas, yaitu aktivitas primer dan aktivitas pendukung. Setiap aktivitas nilai pada rantai merupakan kunci dalam membangun keunggulan bersaingnya. Rantai nilai juga telah banyak digunakan dalam manajemen strategis guna menjawab hubungan jaringan produksi yang melibatkan keseluruhan aktivitas pemasok sampai produk ke tangan konsumen (Porter, 1994).

Adanya globalisasi serta diberlakukannya era perdagangan bebas telah menggeser paradigma bisnis dari comparative advantage menjadi competitive advantage (Kurniaty et al., 2012). Keunggulan komparatif merupakan keunggulan yang ada dalam suatu organisasi seperti sumberdaya manusia dan fasilitas lainnya yang dimanfaatkan untuk mencapai tujuan bersama sedangkan keunggulan kompetitif merupakan keunggulan bersaing yang dimiliki oleh suatu organisasi untuk memiliki nilai lebih dibandingkan organisasi pesaingnya.

Pergeseran paradigma bisnis mengharuskan suatu perusahaan memiliki strategi yang tepat yaitu melalui keunggulan bersaingnya. Keunggulan bersaing dapat dilihat dari berbagai aktivitas yang dilakukan perusahaannya baik dalam mendesain, memproduksi, memasarkan, menyerahkan, serta mendukung produknya. Agar unggul dalam persaingan serta berkelanjutan di pasar, maka UMKM harus mampu membangun keunggulan kompetitifnya (Dalimunthe, 2018). Hal yang dapat dilakukan untuk dapat membangun keunggulan bersaingan dalam suatu UMKM adalah dengan menganalisis rantai nilai yang ada pada setiap aktivitas perusahaan tersebut.

Menurut Maddeppungeng et al., (2015), rantai nilai merupakan langkah awal dalam menentukan posisi perusahaan dalam industri. Rantai nilai ini membagi perusahaan ke dalam 
berbagai aktivitas yang berbeda namun masih saling berkaitan. Terdapat 2 jenis aktivitas rantai nilai yaitu aktivitas primer dan aktivitas pendukung. Aktivitas primer terdiri atas aktivitas logistik ke dalam, logistik ke luar, kegiatan operasi, pemasaran dan penjualan, serta pelayanan. Sementara itu, aktivitas pendukung terdiri atas aktivitas pembelian, pengembangan teknologi, manajemen sumberdaya manusia, serta infrastuktur UMKM (Porter, 1994)

Kota Malang, merupakan salah satu kota yang menghasilkan sayuran. Salah satu sayuran yang di produksi adalah sayur jenis buah yaitu pare. Sayuran buah pare ini dapat diolah menjadi makanan berupa snack krispi yaitu pare krispi. UMKM yang memproduksi pare krispi adalah UMKM D5 Chrispy di Karang Ploso Malang. UMKM D5 ini, merupakan suatu usaha industri makanan ringan.

Pangan diartikan sebagai segala sesuatu yang bersumber dari sumber hayati dan air, baik yang diolah maupun yang tidak diolah. Pengertian pangan menurut PP RI no 28 tahun 2004 bahwa pangan dibagi menjadi pangan segar dan pangan olahan. Pangan segar adalah pangan yang belum mengalami pengolahan dan pangan olahan adalah makanan atau minuman hasil proses dengan metode tertentu

Pangan olahan dibagi dua yaitu pangan olahan kelompok, yaitu pangan olahan yang peruntukan bagi kelompok untuk meningkatkan kualitas kesehatan. Pangan siap saji, yaitu makanan atau minuman yang sudah diolah dan bisa langsung disajikan ditempat usaha atau sesuai pesanan. Untuk mengetahui bagaimana kondisi rantai nilai nya pada saat ini, maka perlu dilakukan penelitian.

Di masa pandemi Covid-19 pada awal tahun 2020 hingga saat ini, Oktober 2020, telah diberlakukan PSBB (Pembatasan Sosial Berskala Besar) dan menerapkan work from home (WFH) dan ini berdampak pada usaha bisnis, salah satunya adalah UMKM. Dengan kondisi tersebut, sudah banyak UMKM yang tutup walaupun ada yang masih bertahan. Bagi UMKM yang masih bisa bertahan, bagaimanakah menjalankan usahanya yang meliputi aktivitas primer dan aktivitas pendukung.

\section{METODE PENELITIAN}

Penentuan lokasi penelitian yaitu Kecamatan Karangploso, Kabupaten Malang yang dipilih secara purposive (sengaja). Pemilihan tersebut atas pertimbangan bahwa Kecamatan Karangploso, Kabupaten Malang di kenal dengan penghasil komoditas sayuran. Komoditas sayuran sifatnya tidak tahan lama sehingga perlu proses pengolahan oleh usaha/industri pengolahan pangan. Salah satu komoditas sayuran adalah sayur pare. Pare dapat diolah menjadi pare krispi. Pengolahan pare menjadi pare krispi diproduksi oleh UMKM D5 Chrispy yang berlokasi di Kecamatan Karangploso Malang. Responden dalam,penelitian ini adalah pemilik UMKM D5 Chrispy Karangploso Malang. Penentuan Responden dipilih secara sengaja (purposive).

Pengumpulan data dilaksanakan dengan cara wawancara dan observasi dengan menggunakan kuisioner dan dokumentasi. Data yang dikumpulkan ada dua macam, yaitu data primer dan data sekunder. Untuk mendapatkan data primer, penelitian ini menggunakan metodologi observasi atau wawancara dengan survei langsung ke UMKM D5 Chrispy. Adapun untuk mendapatkan data sekunder, dilakukan melalui studi literatur.

Metode analisis data yang digunakan dalam penelitian ini meliputi analisis deskriptif dan analisis rantai nilai. Analisis deskriptif adalah menjelaskan tentang aktivitas primer dan pendukung, berdasarkan pengamatan di UMKM D5 Chrispy. Aktivitas primer terdiri atas logistik ke dalam, logistik ke luar, operasi, pemasaran dan penjualan, serta pelayanan. Aktivitas pendukung terdiri atas pembelian, pengembangan teknologi, manajemen sumberdaya manusia, serta infrastruktur perusahaan. Sedangkan analisis rantai nilai adalah model rantai nilai dari Porter. Analisis ini digunakan untuk mengetahui rangkaian aktivitas dari UMKM D5 Chrispy, yang menunjukkan aktivitas mana yang sudah optimal dan aktivitas mana yang belum optimal dalam memberikan kontribusi atas keberhasilan rantai nilai pada UMKM D5 dalam mengolah produk bahan baku hingga menjadi produk jadi. 
Analisis dilakukan melalui pendekatan rantai nilai dan dibantu dengan alat pengukuran berupa scoring. Langkah-langkah dalam menganalisis rantai nilai produk pare krispi di UMKM D5 Chrispy adalah mengidentifikasi setiap kegiatan yang dilakukan , dimulai dari penyediaan bahan baku/ produksi hingga pemasaran produk sampai ke tangan konsumen, mengelompokkan kegiatan yang dilakukan berdasarkan aktivitas primer serta aktivitas pendukung, membuat tabel daftar aktivitas pencipta nilai pada masing-masing aktivitas primer dan aktivitas pendukung, memberikan bobot, bobot relatif, nilai dan skor pada setiap aktivitas rantai nilai, baik aktivitas primer maupun sekunder.

\section{HASIL DAN PEMBAHASAN}

Usaha krispi bernama Delima Krispi yang disingkat dengan D5 Chrispy, didirikan pada tahun 2013, merupakan usaha home industry, usaha swasta perorangan (PO) dan merupakan usaha mikro. Saat ini usaha krispi tersebut telah memiliki Surat Keterangan Halal, PIRT (Produk Industri Rumah Tangga), TDP (Tanda Daftar Perusahaan), SIUP (Surat Ijin Usaha Perdagangan), NPWP (Nomor Pokok Wajib Pajak), dan IUI (Ijin Usaha Industri).

\section{HASIL}

Tabel 1. Konversi Aktivitas Primer Dan Pendukung Menurut Porter, Pada Produk Pare Krispi di UMKM D5 Chrispy, Tahun 2020

\begin{tabular}{|c|c|c|}
\hline Aktivitas & Sub Aktivitas & Konversi \\
\hline \multirow[t]{5}{*}{ Primer } & 1. Logistik ke dalam & $\begin{array}{l}\text { a. Persediaan bahan baku } \\
\text { b. Penyimpanan bahan baku } \\
\text { c. Penggunaan bahan baku }\end{array}$ \\
\hline & 2. Operasi & $\begin{array}{l}\text { a. Pemeliharaan peralatan dan } \\
\text { mesin } \\
\text { b. Proses produksi pare krispi } \\
\text { c. Pengemasan produk }\end{array}$ \\
\hline & 3. Logistik ke luar & $\begin{array}{l}\text { a. Penanganan bahan jadi } \\
\text { b. Pendistribusian }\end{array}$ \\
\hline & 4. Pemasaran dan Penjualan & $\begin{array}{l}\text { a. Promosi } \\
\text { b. Jangkauan pemasaran } \\
\text { c. Penetapan harga produk }\end{array}$ \\
\hline & 5. Pelayanan & $\begin{array}{l}\text { a. Layanan purna jual } \\
b \text {. Interaksi dengan retailer } \\
\text { c. Interaksi dengan konsumen akhir }\end{array}$ \\
\hline \multirow[t]{4}{*}{ Pendukung } & 1. Pembelian & $\begin{array}{l}\text { a. Pembelian perlengkapan } \\
\text { b. Jadwal pembelian bahan baku }\end{array}$ \\
\hline & $\begin{array}{l}\text { 2. Manajemen Sumberdaya } \\
\text { Manusia }\end{array}$ & $\begin{array}{l}\text { a. Rekrutmen karyawan } \\
\text { b. Penjadwalan jam kerja } \\
\text { c. Kompensasi }\end{array}$ \\
\hline & 3. Pengembangan Teknologi & $\begin{array}{l}\text { a. Kelengkapan peralatan } \\
\text { b. Kapasitas mesin produksi }\end{array}$ \\
\hline & 4. Infrastruktur Perusahaan & $\begin{array}{l}\text { a. Manajemen umum } \\
\text { b. Keuangan }\end{array}$ \\
\hline
\end{tabular}

Sumber : Porter (1994) dan Data Primer, 2020

Langkah-langkah untuk memperoleh skor dalam analisis rantai nilai Porter, adalah dengan cara memberikan bobot, bobot relative nilai skor (Si)(Endang dan Harta, 2018) langkah selanjutnya adalah proses normalisasi Snorm De Bour dengan rumus :

$$
\text { Snorm }(\text { Skor })=\frac{(\mathrm{Si}-\mathrm{Smin})}{(\text { Smax }- \text { Smin })} \times 100
$$


Untuk menilai kinerja suatu usaha, nilai Snorm De Bour dibandingkan dengan indikator kinerja dari Volby yang ditunjukkan pada tabel 2 berikut ini.

Tabel 2. Kondisi Indikator Kinerja

\begin{tabular}{ll}
\hline Nilai Indikator Kinerja & Kondisi Indikator Kinerja \\
\hline $0-40$ & Poor \\
$40-50$ & Marginal \\
$50-70$ & Average \\
$70-90$ & Good \\
$90-100$ & Excellent \\
\hline
\end{tabular}

asil perhitungan pembobotan, penilaian, skor dan normalisasi Snorm De Bour diperoleh angka seperti pada Tabel 3.

Tabel 3. Penilaian Kinerja Aktivitas Primer dan Pendukung Dalam Rantai Nilai Porter pada Produk Pare Krispi di UMKM D5 Chrispy, 2020

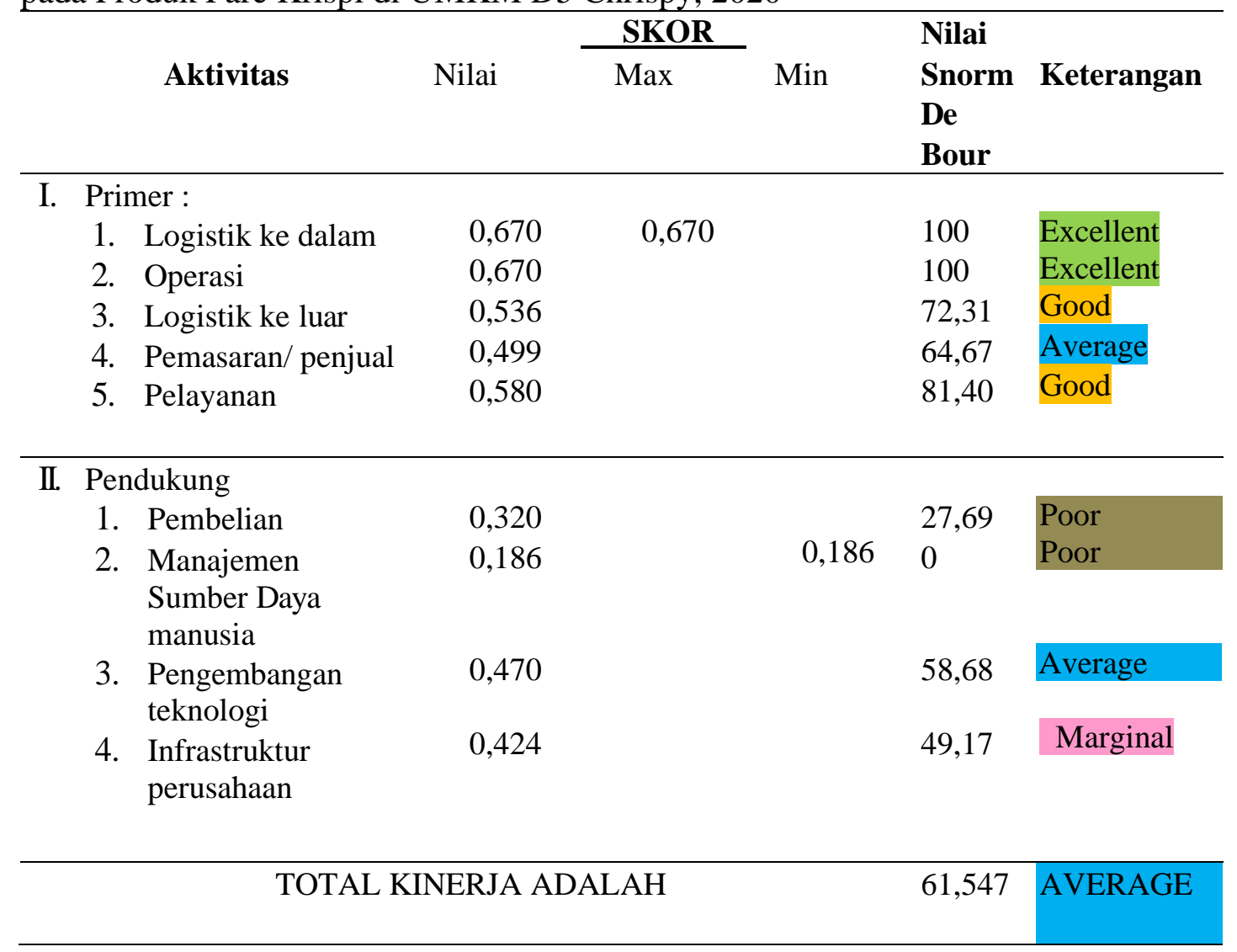

Sumber : Data Primer diolah, 2020 
Dari hasil yang diperlihatkan pada tabel di atas, aktivitas yang mengindikasikan

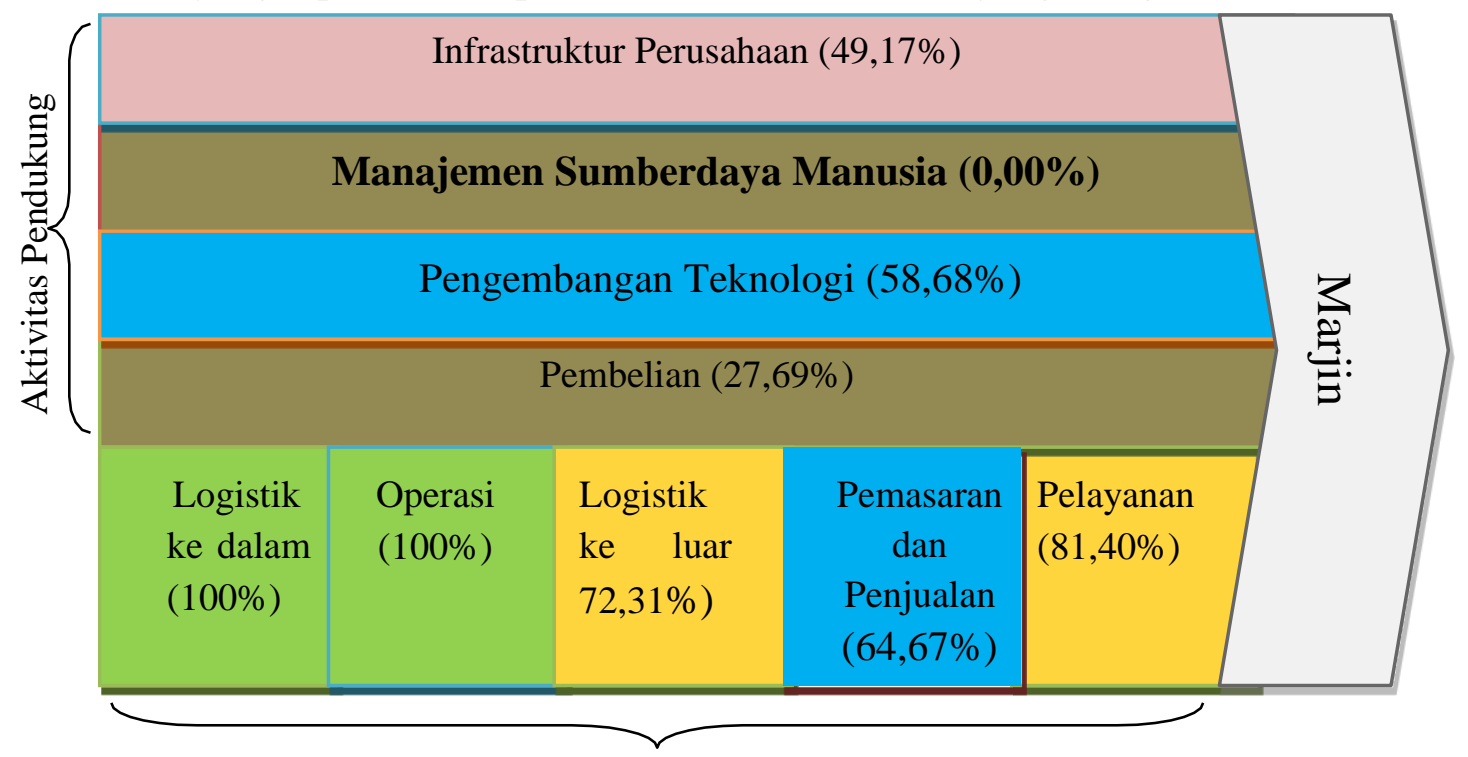

Aktivitas Primer

Keterangan :

Excelent

Good

Average

Marginal

Poor

Gambar 1. Pemetaan Kinerja Aktivitas Primer dan Pendukung Dalam Rantai Nilai Porter pada Produk Pare Krispi di UMKM D5 Chrispy, 2020

Sumber : Data Primer diolah, 2020

\section{PEMBAHASAN}

\section{Analisis Aktivitas Primer dan Pendukung}

Aktivitas suatu usaha menurut Porter (1994) terdiri dari 2 (dua) aktivitas yaitu, aktivitas primer dan aktivitas pendukung. Pada setiap aktivitas akan dilakukan analisis untuk mengetahui kinerjanya serta potensi dalam menciptakan keunggulan bersaing. Pada UMKM D5 Chrispy, konversi aktivitas primer dan pendukung berdasarkan Porter (1994), ditunjukkan pada Tabel 1. Analisis terhadap aktivitas Primer dan pendukung melalui analisis rantai nilai adalah untuk mengetahui kinerja suatu usaha yang menunjukkan aktivitas mana yang sudah optimal dan aktivitas mana yang belum optimal dalam memberikan kontribusi dalam mengolah produk dari bahan baku hingga menjadi produk jadi.

Menurut Porter (1985) dalam Endang dan Harta (2018), aktivitas primer ataupun sekunder yang memiliki skor tertinggi merupakan aktivitas yang berpotensi menciptakan nilai bagi industri dalam rantai nilai untuk menghasilkan produk yang bernilai tambah, sedangkan aktivitas dengan skor terendah merupakan aktivitas yang perlu diperhatikan, karena masih belum optimal dalam menciptakan nilai tambah dalam rantai nilai perusahaan.

\section{Analisis Rantai Nilai pada Aktivitas Primer}

Aktivitas primer dalam suatu usaha, menurut Porter (1994) terbagi dalam 5 kategori generik, yaitu (a) logistik ke dalam, (b) logistik ke luar, (c) operasi, (d) pemasaran dan penjualan,(e) pelayanan. Bobot dan nilai pada aktivitas primer didapatkan dan dihitung berdasarkan hasil wawancara dengan menggunakan alat bantu berupa kuisioner. 
a. Logistik ke dalam

Dari perhitungan pembobotan, penilaian dan skor, aktivitas logistik ke dalam memperoleh nilai skor (Si) sebesar 0,670. Berdasarkan perhitungan Snorm De Bour, aktivitas logistik ke dalam memperoleh skor sebesar 100 (Tabel 3). Menurut Volby (2000), bila hasil skor (Snorm Skor) berada dalam interval 90-100, hal ini mengindikasikan bahwa aktivitas tersebut memiliki kinerja excellent, yaitu kinerja yang sangat baik. Hal ini membuktikan bahwa UMKM D5 Chrisphy sudah sangat baik (excellent) dalam aktivitas logistik ke dalam. UMKM perlu mempertahankan kondisi ini dalam menjalankan usaha memproduksi pare krispi.

b. Operasi

Perhitungan pembobotan, penilaian, dan skor pada Tabel 3, aktivitas operasi memperoleh skor 0,670. Berdasarkan perhitungan dengan cara Snorm De Bour, aktivitas operasi memperoleh skor sebesar 100 (Tabel 3). Menurut Volby (2000) bila hasil skor (Snorm skor) berada dalam interval 90-100 menunjukkan aktivitas tersebut memiliki kinerja excellent. Hal ini membuktikan bahwa aktivitas tersebut memiliki kinerja yang excellent, yaitu kinerja yang sangat baik. Hal ini membuktikan bahwa UMKM D5 Chrispy sudah sangat baik (excellent) dalam aktivitas operasinya. UMKM perlu mempertahankan kondisi ini dalam menjalankan usahanya memproduksi pare krispi.

\section{c. Logistik keluar}

Berdasarkan perhitungan pembobotan, penilaian dan skor pada Tabel 3, aktivitas logistik ke luar memperoleh nilai skor ( $\mathrm{Si}$ ) sebesar 0,536. Berdasarkan perhitungan Snorm De Bour, logistik ke luar memperoleh skor sebesar 72,31 (Tabel 3). Menurut Volby (2000), bila hasil skor (Snorm Skor) berada dalam interval 70-90, hal ini mengindikasikan bahwa aktivitas tersebut memiliki kinerja good, yaitu kinerja yang baik. Hal ini membuktikan bahwa UMKM D5 Chrisphy telah menjalankan aktivitas logistik ke luar dengan baik (good). Kinerja aktivitas ini perlu dipertahankan atau ditingkatkan untuk mencapai kinerja yang excellent.

\section{d. Pemasaran dan Penjualan}

Berdasarkan perhitungan pembobotan, penilaian dan skor yang ditunjukkan pada Tabel 3, aktivitas pemasaran atau penjualan, memperoleh nilai skor ( $\mathrm{Si}$ ) sebesar 0,499. Berdasarkan perhitungan dengan cara Snorm De Bour, aktivitas pemasaran/penjualan memperoleh skor 64,67 (Tabel 3). Skor Snorm de Bour yang berada dalam interval 5070 menunjukkan aktivitas tersebut memiliki kinerja average yaitu kinerja rata-rata atau kinerja yang cukup. Hal ini membuktikan bahwa UMKM D5 Chrispy telah melaksanakan aktivitas pemasaran/penjualan yang cukup (average) dalam promosi, jangkauan pemasaran dan dalam penetapan harga. Promosi secara online dan offline pelaksanaannya belum rutin. Untuk mencapai kondisi harga yang excellent, perlu peningkatan kinerja pemasaran/penjualan.

e. Pelayanan

Berdasarkan perhitungan pembobotan, penilaian dan skor yang ditunjukkan pada Tabel 3, aktivitas pelayanan memperoleh skor ( $\mathrm{Si}$ ) sebesar 0,580. Berdasarkan perhitungan dengan cara Snorm De Bour, aktivitas pelayanan memperoleh skor sebesar 81,40 (Tabel 3). Menurut Volby (2000) bila skor (Snorm Skor) berada dalam interval 70-90. Hal ini mengindikasikan aktivitas tersebut memiliki kinerja good, yaitu kinerja yang baik. Hal ini membuktikan bahwa UMKM D5 Chrispy sudah baik dalam menjalankan aktivitas pelayanan. Untuk mencapai kinerja yang excellent, maka kinerja aktivitas pelayanan perlu ditingkatkan. 


\section{Analisis Rantai Nilai pada Aktivitas Pendukung}

Aktivitas pendukung merupakan serangkaian aktivitas yang dapat mendukung aktivitas primer serta mendukung aktivitas satu sama lainnya. Menurut Porter (1994), aktivitas pendukung terbagi atas empat kategori generik, yaitu (a) pembelian, (b) sumberdaya manusia, (c) teknologi dan (d) infrastruktur perusahaan.

a. Pembelian

Berdasarkan perhitungan pembobotan penilaian dengan skor, yang ditunjukkan pada Tabel 3, aktivitas pembelian memperoleh skor 0,320. Berdasarkan perhitungan dengan cara Snorm De Bour, aktivitas pembelian memperoleh skor sebesar 27,69 (Tabel 3). Menurut Volby (2000), bila skor (Suorm skor) berada dalam interval 0-40, hal ini menunjukkan bahwa aktivitas tersebut memiliki kinerja yang poor, yaitu kinerja yang buruk. Hal ini menunjukkan bahwa aktivitas tersebut, yaitu pembelian, perlu mendapat perhatian. Terutama pembelian peralatan.

b. Manajemen Sumber Daya Manusia

Berdasarkan perhitungan pembobotan, penilaian dan skor yang ditunjukkan pada Tabel 3, aktivitas manajemen sumber daya manusia memperoleh skor 0,186. Berdasarkan perhitungan dengan cara Snorm De Bour, aktivitas manajemen sumber daya manusia memperoleh skor sebesar 0 (nol), lihat Tabel 3. Menurut Volby (2000) bila skor (Snorm skor) berada dalam interval 0-40, hal ini menunjukkan bahwa aktivitas tersebut memiliki kinerja yang poor, yaitu kinerja yang buruk. Hal ini menunjukkan bahwa aktivitas tersebut perlu mendapat perhatian. Selama ini UMKM D5 Chrispy menjalankan usahanya secara mandiri atau sendiri tanpa karyawan (tenaga orang lain). Kondisi yang poor ini perlu dikelola lebih baik lagi.

c. Pengembangan Teknologi

Berdasarkan perhitungan pembobotan, penilaian dan skor yang ditunjukkan pada Tabel 3, aktivitas pengembangan teknologi memperoleh skor (Si) sebesar 0,470. Berdasarkan perhitungan dengan cara Snorm De Bour, aktivitas pengembangan teknologi memperoleh skor sebesar 58,68 (Tabel 3). Menurut Volby (2000) bila skor (Suorm skor) berada dalam interval 50-70, hal ini menunjukkan aktivitas tersebut memiliki kinerja yang Average, yaitu kinerja yang rata-rata, kinerja yang cukup. UMKM D5 Chrispy dalam hal pengembangan teknologi sudah dinilai cukup dalam kelengkapan peralatan, penggunaan kapasitas alat produksi dan cukup dalam aktivitas ini, UMKM perlu peralatan yang lebih modern. Ini terkait dalam ada hubungannya dengan aktivitas pembelian terutama untuk perlengkapan/peralatan.

d. Infrastruktur Perusahaan

Berdasarkan perhitungan pembobotan, penilaian dan skor, yang ditunjukkan pada Tabel 3, aktivitas untuk infrastruktur perusahaan memperoleh skor ( $\mathrm{Si}$ ) sebesar 0,424. Berdasarkan perhitungan dengan cara Snorm De Bour, aktivitas untuk infrastruktur perusahaan, memperoleh skor 47,17 (Tabel 3). Menurut Volby (2000) bila skor (Suorm skor) berada dalam interval 40-50, hal ini menunjukkan bahwa aktivitas tersebut memiliki kinerja yang marginal, yaitu kinerja yang terpinggirkan dalam hal pelaksanaan managemen umum. Pencatat keuangan sudah meliputi biaya-biaya penerimaan dari pendapatan, juga terdapat catatan debit dan kredit.

\section{KESIMPULAN}

Berdasarkan tujuan dan hasil penelitian mengenai kinerja rantai nilai pada produk pare krispi di UMKM D5 Chrispy, maka dapat diambil kesimpulan sebagai berikut :

1. Aktivitas primer pada rantai nilai yang memiliki skor tertinggi yang sama besarnya adalah aktivitas logistik ke dalam dan aktivitas operasi, dengan kinerja yang excellent. Aktivitas ini merupakan aktivitas yang berpotensi menciptakan nilai bagi usaha dalam rantai nilai dan berpotensi sebagai aktivitas keunggulan bersaing.

2. Aktivitas pendukung yang memiliki skor tertinggi adalah pada aktivitas pengembangan teknologi dengan kinerja yang average, memiliki teknologi peralatan yang cukup 


\section{DAFTAR PUSTAKA}

Dalimunthe, M. B. (2018). Keunggulan Bersaing Melalui Orientasi Pasar dan Inovasi Produk. Jurnal Konsep Bisnis Dan Manajemen, 3(1).

Elias, Melissa Carnia. (2018). Analisis Strategi Bersaing pada Perusahaan Biro Perjalanan di Malang. Jurnal AGORA 6(2)-1-6. Dari https://www.neliti.com. Diakses pada tanggal 14 Oktober, pukul 03.25 WIB.

Endang,M. H.Haryadi. (2018). Analisis Bobot dan Peringkat Porter untuk Mengetahui Aktivitas Yang Paling Berpengaruh Dalam Rantai Nilai Mineral Bijih Besi di Indonesia. Jurnal Teknologi Mineral dan Batubara 14(2):127-139, from http://DOI: 10.30556/jtmb.Vol14.No2.2018.407.

Kurniaty, R. M., Fauzi, A. M., \& Chozin, M. A. (2012). Daya Saing PT Benar Flora Utama Berdasarkan Aktivitas Rantai Nilai Florikultura. J Manajemen \& Agribisnis 9(3):146153.

Maddeppungeng, A., Suryani, I., \& Herlambang, F. (2015). Analisis Pengaruh Value Chain Terhadap Keunggulan Bersaing Dalam Mencapai Kepuasan Kontraktor pada Perusahaan Ready Mix Beton di Banten. Jurnal Fondasi, 4(1).

Porter, M. E. (1994). Keunggulan Bersaing: Menciptakan dan Mempertahankan Kinerja Unggul. Jakarta: Binar.

Volby. (2000). Performance Measurement and Improvement Supply Chain. International Journal of Physical Distribution \& Materials Management., (Thinekers). 